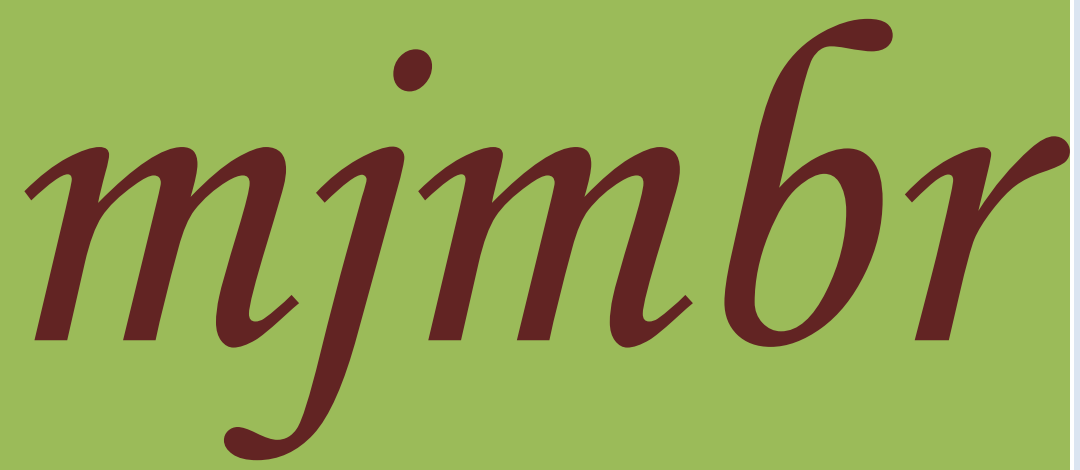

Malaysian Journal of Medical and Biological Research

www.jmbr-my.weebly.com

Vol 1, No. 1, 2014 


\title{
Antibacterial Effects of Ocimum Sanctum L Leaves, Flowers and Shoots against Bacillus spp from Soil
}

\author{
Md. Azizul Islam, Md. Abul kalam Azad, Md.Rezaul Karim, Sudhangsu Kumar \\ Biswas, Md. Mostafizur Rahmam, \& Md. Mafizur Rahman
}

Department of Biotechnology and Genetic Engineering, Islamic University, Kushtia- 7003, Bangladesh

\begin{abstract}
In this study, the antibacterial activity of various organic solvent extracts of Ocimum sanctum L leaves, flowers and shoots was determined in vitro using agar diffusion method and MIC tested against the isolated soil bacteria. The identified bacteria were Paenibacillussp. L32, Paenibacillussp. BF38, Bacillus megaterium, Terribacillussp. 3LF, Bacillus simplex and Bacillus cereus. Various organic extracts of Ocimum sanctum $\mathrm{L}$ revealed a good antibacterial activity against about all bacteria. Results showed that the best extract was methanol because highest inhibition zone were obtained by this extract and all studied bacteria were inhibited. At a concentration of 500 $\mu \mathrm{g} /$ disc, the highest microbial inhibition was found $19.2 \pm .76 \mathrm{~mm}$ against Bacillus simplex for methanol extract, $15.7 \pm 0.58 \mathrm{~mm}$ on Terribacillus sp. $3 \mathrm{LF}$ for ethanol extract of flower, $14.0 \pm 2.0 \mathrm{~mm}$ on Terribacillus sp. 3LF for ethanol extract of leaves, $13.34 \pm 0.58 \mathrm{~mm}$ on Bacillus megaterium for n-hexane extract and $11.7 \pm 0.6 \mathrm{~mm}$ on Terribacillus sp. 3LF for chloroform extract, respectively and MIC (64, 128, 256 and $512 \mu \mathrm{g} / \mathrm{ml}$, respectively). Most of the cases, antibacterial activity with commercial antibiotics such as amoxicillin and erythromycin, organic extracts exhibited similar or higher antibacterial activity than standard drug. The results of this study suggest that the organic extracts of Ocimum sanctum L leaves can be a source of natural antimicrobial agents with potential applications.
\end{abstract}

Keywords: Antibacterial; $16 \mathrm{~S}$ rDNA sequence; Bacillus sp; Different extract; Ocimum sanctum $\mathrm{L}$

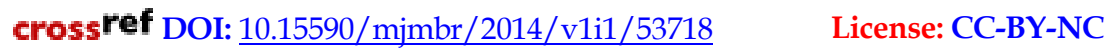

\section{INTRODUCTION}

Pathogenic bacterial strains show multiple antibiotic drug resistance which is a major medical problem worldwide and poses a big threat to human society. Beside this most of the antibiotics have side effects and also they are expensive too (Londonkar et al 2013). Herbal treatment is one possible way to treat disease caused by multidrug resistant bacteria( Rahman et al 2011, Aliero et al 2006, Alam et al 2009) which is the basis for the study. The screening of plant extracts and plant products for antimicrobial activity has shown that higher plants represent a potential source of novel antibiotic prototypes (Afolayan, 2003). The trend of using natural products has increased and the active plant extracts are frequently screened for new drug discoveries and for the presence of antimicrobial substances (Hosseinzadeh et al., 2007). There has been an increasing 
incidence of multiple resistances in human pathogenic microorganisms in recent years, largely due to indiscriminate use of commercial antimicrobial drugs commonly employed in the treatment of infectious diseases (Parekh and Chanda, 2007). There is extensive scientific literature on the antimicrobial potential of spices that have been reviewed by several researches (Chaudhry and Tariq, 2008).

Members of the aerobic spore-forming genus Bacillus spp. and other closely related species can be recovered from almost every environment in the biosphere. Bacillus spp and related genera have been associated with food spoilage such as ropy bread (Thompson et al., 1998; Sorokulova et al., 2003) besides causing several human infections that cause a range of diseases (Callegan et al., 2006;Tena et al., 2007), and incidents of food borne illness (Dierick et al., 2005). Recent advances in the use of Bacillus spp. are emphasized. There is a considerable interest in using Bacillus subtilis producing lipopeptide antibiotics like iturin A and surfactin (Bais et al., 2004). Bacillus species produce many kinds of antibiotics which share a full range of antimicrobial activity such as bacitracin, pumulin and gramicidin (Todar, 2005).

Ocimum sanctum L. (OS, Tulsi), a medicinal herb used in the indigenous system of medicine. OS has been adored in almost all ancient ayurvedic texts for its extraordinary medicinal properties. The roots, leaves and seeds of Tulsi possess several medicinal properties. OS is a medicinal plant of Bangladesh and Indian subcontinent, which is widely used as traditional healthcare system, as a stomachic and anthelmintic as well as in purulent discharge of the ear, bronchitis, hiccough, diuretic and diseases of the heart and brain. People use its leaf extract along with honey to cure cold and cough, chronic pain in the joints, asthma and enlarged spleen. In the Yunani system of treatment, it is believed that the juice gives luster to the eye, good for toothache, earache, headache and cure of ringworm. It is also used in the treatment of snakebite and other similar purposes (Prakash et al.2005, Kirtikar and Basu 1994).

It has several medicinal properties have been attributed to act on the human body mainly as a cough alleviator, a sweat-inducer and a mitigator of indigestion and anorexia. OS has a variety of biological/pharmacological activities such as antibacterial, antiviral, antifungal, antiprotozoal, antimalarial, anthelmentic, antidiarrhoeal, anticancer activity, chemopreventive activity, radioprotective activity, antioxidant activity, antihypertensive and cardioprotective activities, antiinflammatory activity, analgesic activity, memory enhancer activity, hepatoprotective activity, antifertility activity, antidiabetic activity, antiulcer activity, antiarthritic activity, adaptogenic activity/antistress activity, anticataract activity, anticoagulant activity and many among. In addition, the phenolic compounds have been also identified which exhibit antioxidant and antiflammatory activities. The nutritional and pharmacological properties of the whole herb in its natural form, as it has been traditionally used. Its leaf contain volatile oil eugenol, eugenal ( also called eugenic acid ), urosolic acid, carvacrol, linalool, limatrol, caryophyllene, methyl cervical ( also called Estragol), saponins, flavonoids, triterpenoids and tannins ( Kelm et al.,2000; Pattanayak et al.,2010; Shishodia et al., 2003, Jaggi et al., 2003 ). Therefore, the aim of this study was to evaluate the antimicrobial activities of the various organic extracts of the Ocimum sanctum leaves, shoots and flowers. 


\section{Materials AND Methods}

\section{Isolation and identification of bacteria from soil}

$20 \mathrm{~g}$ of fresh collected soil were suspended in sterile $\mathrm{NaCl}(0.9 \%)$ and maintained on a rotary shaker for $45 \mathrm{~min}$ at the maximum speed. The suspension was serially diluted, plated on PCA (Plate Count Agar) medium ( $\mathrm{pH} 7.0$, Sigma) and incubated at $30^{\circ} \mathrm{C}$ under aerobic conditions for 15 days. Most representatives colonies were randomly collected from plates, purified by streaking twice and stored as stock cultures in $20 \%$ (v/v) glycerol at $-80^{\circ} \mathrm{C}$ for their genetic identification by $16 \mathrm{~S} \mathrm{rDNA}$ sequencing as previously described (McCaig et al., 2001). PCR was performed in a final volume of $25 \mu$ l containing buffer 10X, 1.0 unit of TaqDNA polymerase (Amersham Biosciences), $0.2 \mathrm{mM}$ each of dNTPs, $200 \mathrm{nM}$ of each primer 63F 5'CAGGCCTAACACATGCAAGTC (Marchesi et al., 1998) and 1389R 5'ACGGGCGGTGTGTACAAG (Osborn et al., 2000) and $50 \mathrm{ng}$ template DNA. The thermal cycler (Bio Rad ICycler 170-8740) was programmed for the initial denaturation step $\left(94^{\circ} \mathrm{C}\right)$ of $5 \mathrm{~min}$, followed by 44 cycles of $1 \mathrm{~min}$ denaturation along with $1 \mathrm{~min}$ primer annealing $\left(37^{\circ} \mathrm{C}\right)$ and $2 \mathrm{~min}$ primer extension $\left(72^{\circ} \mathrm{C}\right)$, followed by the $7 \mathrm{~min}$ primer extension $\left(72^{\circ} \mathrm{C}\right)$ step. The amplified DNA was visualized by gel electrophoresis. The most similar bacterial species was found in the GenBank by using BLAST search (http://www.ncbi.nlm.nih.gov). Neighbor-joining phylogenetic trees were constructed based on 16S rDNA sequences using Jalview version 2.7.

\section{Plant material}

The leaves of Ocimum sanctum L.were collected from local market of Kushtia of Bangladesh in March 2011 and identified by Professor Sk. Shamimul Islam, Department of Botany, University of Dhaka, Bangladesh. The voucher specimen has been deposited in Bangladesh National Herbarium, Dhaka.

\section{Preparation of Organic Extracts}

The air-dried leaves, flowers and shoots of Ocimum sanctum L. were first pulverized into powdered form. The dried powder $(50 \mathrm{~g})$ was then extracted with n-hexane, chloroform, ethanol and methanol separately at room temperature for 7 days and the solvents were evaporated by vacuum rotary evaporator temperature at $50^{\circ} \mathrm{C}$. The extraction process yielded n-hexane (7.3 g), chloroform (6.2g), ethanol (7.4 g) and methanol (6.5 g) extracts respectively. Solvents (analytical grade) for extraction were obtained from commercial sources (Sigma-Aldrich, St. Louis, MO, USA).

\section{Isolation and Identification of Bacteria}

DNA was extracted from soil isolates were subjected to PCR to amplify for identification bacterial species and amplified DNA products were confirmed by Gel Electrophoresis through the visualization of their band patterns. Based on the 16S rDNA sequences, the bacteria were confirmed as the following Bacillus $s p$. according to my published paper Rahman et al. (2013). The six isolated bacillus spp are Bacillus megaterium, Bacillus simplex, Terribacillus sp. 3LF, Bacillus cereus, Paenibacillus sp. L3, Paenibacillus sp. BF38, and the accession number are FJ614260, FJ225298, AM931170, EU741083, DQ196465, AM934687 respectively.

\section{Antibacterial assay}

The dried extracts were dissolved in the same solvent used for their extraction and sterilized by filtration using $0.22 \mu \mathrm{m}$ sterile Millipore filter (Millipore Corp., Billerica, MA, USA). Then the antibacterial test was carried out by agar disc diffusion method (Murray et al., 1995) using $100 \mu \mathrm{l}$ of standardized inoculums suspension containing $10^{7} \mathrm{CFU} / \mathrm{ml}$ of bacteria. The essential oil was diluted 1:5 (v/v) with methanol and aliquots of $10 \mu \mathrm{l}$ were 
spotted onto the sterile Whatman No. 1 filter paper discs (6 mm diameter); while $10 \mu \mathrm{l}$ of $30 \mathrm{mg} / \mathrm{ml}$ of each organic extract $(300 \mu \mathrm{g} /$ disc) was applied on the filter paper discs and placed on the inoculated LB agar medium. Negative controls were prepared using the same solvents employed to dissolve the samples. Standard antibiotic, amoxicillin $(10 \mu \mathrm{g})$, cloxacilin $(5 \mu \mathrm{g})$, and Tetraciline $(30 \mu \mathrm{g})$ from Sigma-Aldrich Co., St. Louis, MO, USA) was used as positive control for the tested bacteria. The plates were incubated micro aerobically at $37{ }^{\circ} \mathrm{C}$ for $24 \mathrm{~h}$. Antibacterial activity was evaluated by measuring the diameter of the zones of inhibition against the tested bacteria. Each assay in this experiment was replicated three times.

\section{Minimum inhibitory concentration (MIC)}

The minimum inhibitory concentration (MIC) of nano emulsions was assessed according to Al-Reza et al (2011). Active cultures for MIC determination were prepared by transferring a loopful of cells from the stock cultures to flasks and inoculated in LB medium and incubated at $37^{\circ} \mathrm{C}$ for $24 \mathrm{~h}$. The nanoemulsions were incorporated into LB broth medium to get the final concentration ranging from 0 to $1000 \mu \mathrm{g} / \mathrm{ml}$. Finally, $20 \mu \mathrm{l}$ inoculums of each bacteria strain $\left(10^{7} \mathrm{CFU} / \mathrm{ml}\right)$ was transferred to each tube and the tests were performed in a volume of $2 \mathrm{ml}$. The control tube contained only organisms and not the nano emulsion. The culture tubes were incubated at $37^{\circ} \mathrm{C}$ for $24 \mathrm{~h}$. The lowest concentration of the test samples, which did not show any visual growth of tested organisms after macroscopic evaluation, was determined as MIC, which was expressed in $\mu \mathrm{g} / \mathrm{ml}$.

\section{RESULTS}

\section{Antibacterial activity of various extracts of leaves, flower and shoots of Ocimum sanstum L.}

Antibacterial activity various extracts (ethanol, chloroform, n-hexane and methanol) of Ocimum sanctum L. flowers, shoots and leaves against the bacteria was qualitatively assessed by the presence of inhibition zones. According to the results given in Table 1, a total of six isolated soil bacteria, were tested. Various organic extracts of flowers, shoots and leaves of Ocimum sanctum L. also revealed a good antibacterial activity against most of the bacteria, at a concentration of $500 \mu \mathrm{g} /$ disc (Table 1). Antibacterial activity of different extracts of Ocimum sanctum L. flower, shoots and leaves is shown in table 1 in a comparative way with standard

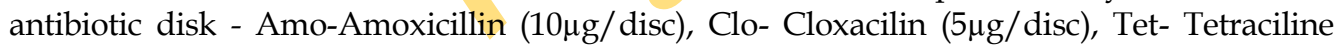
$(30 \mu \mathrm{g} / \mathrm{disc})$. The present study revealed that the methanol extract of leaves possessed the highest zone of inhibition $(19.2 \pm .76 \mathrm{~mm})$ against Bacillus simplex. This is followed by $18.5 \pm 0.5$ $\mathrm{mm}$ and $17.5 \pm 0.5 \mathrm{~mm}$ against bacillus cereus and Terribacillus sp. 3LF respectively. Ethanol extract of leaves produced satisfactory sensitivity with inhibition zones in the range of $6.5 \pm 1.04$ and $14.0 \pm 2.0 \mathrm{~mm}$ whereas ethanol extracts of shoots and flowers showed relatively poor antibacterial effect account for the range from $9.5 \pm 0.5$ to $13.5 \pm 0.5$ and $8.5 \pm .5$ to $15.7 \pm 0.58$, respectively. Methanol extract showed the strongest effect against Bacillus simplex (inhibition zone 19.2 .76), compared with standard drug amoxicillin, Cloxacilin, tetracycline. On the other hand, n-hexane and choloroform extracts showed interesting antibacterial effect with inhibition zones in the range of $11.7 \pm 0.58 \sim 14.0 \pm 1.0$ and $8.4 \pm 0.58 \sim 11.7 \pm 0.6 \mathrm{~mm}$, respectively. In some cases organic extracts (ethanol, chloroform, n-hexane and ethanol) exhibited higher antibacterial activity compared with amoxicillin, Cloxacilin while tetracycline showed higher activity in some other cases than the solvent extracts. Positive control produced significant zone of inhibition against most of the bacteria while no zone of inhibition was formed by negative control. 
Malaysian Journal of Medical and Biological Research, Volume 1, No 1 (2014)

Table 1, Antibacterial activity of various organic extracts of leaves, flowers and shoots of Ocimum sanctum L.

\begin{tabular}{|c|c|c|c|c|c|c|c|c|c|}
\hline \multirow{3}{*}{ Name of Bacteria } & \multicolumn{4}{|c|}{ Extracts } & \multirow{3}{*}{$\begin{array}{c}\text { Flower } \\
\text { EtOH }\end{array}$} & \multicolumn{4}{|c|}{ Antibiotics } \\
\hline & \multicolumn{4}{|c|}{ Leaf } & & \multirow{2}{*}{$\begin{array}{l}\text { shoot } \\
\text { EtOH }\end{array}$} & \multirow[b]{2}{*}{ Amo-10 } & \multirow[b]{2}{*}{ Clo-5 } & \multirow[b]{2}{*}{ Tet-30 } \\
\hline & $\mathrm{MeOH}$ & $\mathrm{EtOH}$ & $\mathrm{CHCl}_{3}$ & n- Hexane & & & & & \\
\hline Bacillus simplex & $19.2 \pm .76$ & $10.0 \pm 1.0$ & - & $11.7 \pm 0.58$ & - & $11.8 \pm 0.3$ & $12.6 \pm 0.5$ & $15.0 \pm 1.0$ & $18 \pm 1$ \\
\hline Paenibacillus sp.BF38 & $14.5 \pm 0.5$ & $12.5 \pm 0.5$ & - & - & - & $11 \pm 1$ & $10.8 \pm 0.8$ & - & $19 \pm 1$ \\
\hline Terribacillus sp. $3 L F$ & $17.5 \pm 0.5$ & $14.0 \pm 2.0$ & $11.7 \pm 0.6$ & $12.3 \pm 0.58$ & $15.7 \pm 0.58$ & $11 \pm 1$ & $11 \pm 1$ & $16.7 \pm 1.5$ & $14.5 \pm 0.5$ \\
\hline Bacillus megaterium & $14.0 \pm 1.0$ & $11.6 \pm 1.04$ & $11 \pm 1$ & $13.34 \pm 0.58$ & $14.67 \pm 1.5$ & $13.5 \pm 0.5$ & $11 \pm 0.4$ & $10.8 \pm 0.8$ & $12 \pm 1$ \\
\hline Paenibacillus sp. L32 & - & $6.5 \pm 1.04$ & - & - & - & - & $11 \pm 1$ & $11 \pm 1$ & - \\
\hline Bacillus cereus & $18.5 \pm 0.5$ & $11.0 \pm 1.0$ & $8.4 \pm 0.58$ & $14 \pm 1$ & $8.5 \pm .5$ & $9.5 \pm 0.5$ & $13.5 \pm 0.5$ & $12.5-$ & $14.7 \pm 0.6$ \\
\hline
\end{tabular}

* Diameter of inhibition zones $(\mathrm{mm})$ around the discs $(6 \mathrm{~mm})$ impregnated with10 $\mu \mathrm{L}$ of 1:5 (v/v) dilution with ethanol.

*Various organic extracts $(512,256,128, \mu \mathrm{g} /$ disc), (-) mean no detected

The standard antibiotics were amoxicillin and erythromycin $(10 \mu \mathrm{g} / \mathrm{disc})$

Values are given as mean \pm S.D of triplicate experiment.

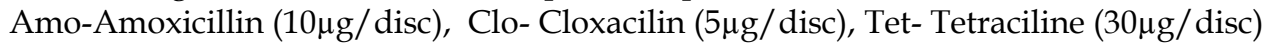

\section{Minimum inhibitory concentration (MIC)}

As shown in (Table 2), MIC values of various extracts were found between $64-512 \mu \mathrm{g} / \mathrm{ml}$ and the best MIC values was $64 \mu \mathrm{g} / \mathrm{ml}$ against Terribacillus sp. 3LF by ethanol extract from flower parts of Tulsi The MIC values of the organic extracts of methanol, ethanol, chloroform and n-hexane against the bacteria tested were found in the range 64-512 $\mu \mathrm{g} / \mathrm{ml}$. In this study, Bacillus spp were found to be more susceptible to the ethanol.

Table 2, Minimum inhibitory concentration (MIC) of organic extracts of leaves of Piper betel L

\begin{tabular}{|c|c|c|c|c|c|c|}
\hline \multicolumn{7}{|c|}{ Minimum inhibitory concentration $(\mu \mathrm{g} / \mathrm{ml})^{\mathrm{a}}$} \\
\hline \multicolumn{7}{|c|}{ Organic extracts } \\
\hline & & & af & & & Flower Shoot \\
\hline Microorganisms & $\mathrm{MeOHe}$ & $\mathrm{EtOH}^{\mathrm{b}}$ & $\mathrm{CHCl}_{3} \mathrm{c}$ & n-Hexaned & $\mathrm{EtOH}^{\mathrm{b}}$ & $\mathrm{EtOH}^{\mathrm{b}}$ \\
\hline Bacillus simplex & 512 & - & 256 & 256 & - & 256 \\
\hline Paenibacillus sp.BF38 & 256 & - & - & 256 & - & 256 \\
\hline Terribacillus sp. 3LF & 256 & 256 & 256 & 256 & 64 & 256 \\
\hline Bacillus megaterium & 256 & 256 & 128 & 256 & 128 & 256 \\
\hline Paenibacillus sp. L32 & 512 & - & - & - & - & - \\
\hline Bacillus cereus & 512 & 512 & 128 & 128 & 256 & 256 \\
\hline
\end{tabular}
a Minimum inhibitor concentration (MIC).
b Ethanol extract
c Chloroform extract
d n-Hexane extract
e Methanol

\section{Discussion}

Bacteria, virus, fungi and parasites are the major causative agent of various infectious diseases which are becoming this is a public concern especially in developing countries due to unavailability and high cost of medicine (Radfer, et al. 2012). This is the reason for conducting this research as we evaluate the antibacterial activities of Ocimum sanctum L. flowers shoots and leaves.

Plants have provided a source of inspiration for novel drug compounds as plants derived medicines have made significant contribution towards human health. Recently, multiple drug resistance has developed due to indiscriminate use of commercial antimicrobial drugs that are commonly used in the treatment of infectious diseases, making it a global 
growing problem (Parekh and Chanda, 2007). A novel approach to the prevention of antibiotic resistance of pathogenic species is the use of new compounds that are not based on existing synthetic antimicrobial agents (Shah, 2005). Plants have provided a source of inspiration for novel drug compounds as plants derived medicines have made significant contribution towards human health (Seikh et al., 2010 ) which compound exist in Ocimum sanctum L. contributes to cause antimicrobial activities is yet unknown. In this study we found that various leaf extracts of Piper betel L severely inhibited the growth of some representative food spoilage and human infection pathogens, which might have significant applications in the pharmaceutical or food industries. Therefore, plant extracts are being considered as potential alternatives to synthetic bactericides or as lead compounds for developing new classes of natural antimicrobial agents.

\section{Conclusions}

In conclusion, the results of this study suggest that the leaves of Piper betel L mediated organic extracts could be a source of natural antimicrobial agents that can be used as antimicrobial agent $\mathrm{s}$ in designing and and developing new drugs and also utilization for food or pharmaceutical industries to control pathogenic bacteria. Further study is in preparation, purification and characterization to evaluate the bioactive compounds present in various organic extracts of leaves of Piper betel L. However, if plant-based antimicrobials such as crude extracts are to be used for drug or food preservation, issues of safety and toxicity will always need to be addressed.

\section{REFERENCES}

Afolayan, A. J. Extracts from the shoots of Arctotisartotoides inhibit the growth of bacteria and fungi. Pharmaceutical Biology. 2003, 4, 22-25.

Alam, M. Karim, M. Khan, S. N. Antimicrobial mactivity of different organic extracts of Achyranthes aspera and Cassia alata. Journal of Scentific Research. 2009, 1(2),393-398.

Aliero, A., Afolayan, A. Antimicrobial activity of Solanum tomentosum. African Journal of Biotechnoogy. 2006, 5(4), 369-372.

Al-Reza, S. M., Rahman, A., Parvin, T., Rahman, M. M., and Rahman, S. M. (2011). Chemical composition and antibacterial activities of essential oil and organic extracts of Curcuma aromatic Salisb. Journal of Food Safety .31, 433-438.

Bais, H. P., Fall, R., Vivanco, J. M. Biocontrol of Bacillus subtilis against infection of Arabidopsis roots by Pseudomonas syringae is facilitated by biofilm formation and surfactin production. Plant Physiology. 2004, 134, 307-319.

Callegan, M., Cochran, D., Kane, S., Ramadan, R., Chodosh, J., Mclean, C., and Stroman, D. Virulence factor profiles and antimicrobial susceptibilities of ocular Bacillus isolates. Current Eye Research. 2006, 31, 693-702.

Chaudhry, N. M. A., and Tariq, A. (2008).In vitro antibacterial activities of kalonji, cumin and poppy seed. Pakistan Journal of Botany. 40, 461-467.

Dierick, K., Van, C. E., Swiecicka, I., Meyfroidt, G., Devlieger, H., Meulemans, A., Hoedemaekers, G., Fourie, L., Heyndrickx, M., and Mahillon, J. Fatal family outbreak of Bacillus cereus-associated food poisoning. Journal of Clinical Microbiology. 2005, 43, 4277-9.

Hosseinzadeh, H., Bazzaz, F.B. S., and Haghi, M. M. Antibacterial activity of Total Extracts and Essential oil of Nigella Sativa L. Seeds in Mice. Pharma.On line. 2007, 2, 429-435.

Kelm, M.A, Nair, M.G, Strasburg, G.M, DeWitt, D.L, Antioxidant and cyclooxygenase inhibitory phenolic compounds from Ocimum sanctum Linn. Phytomedicine. , 2000, 7(1),7-13.

Kumar, N.l, Pragya, M., Anuradha, D., Shailja, B. ,Madhu, $\quad$ D., and Shirish, R. Piper betel Linn.A maligned Pan-Asiatic plant with an array of pharmacological activities and prospects for drug discovery.Current Science. 2010. 99, 922-932. 
Londonkar, R.L, Kattegouga, M.U. Shivsharanappa, K. Hanchinalmath, J.V: Phytochemical screening and in vitro antimicrobial activity of Typha angustifolia Linn leaves extract against pathogenic gram negative micro organisms. Journal of Pharmacological Res earch. 2013, 6(2), 280-283.

Marchesi, J. R., Sato, T., Weightman, A. J., Martin, T. A., Fry, J. C., Hiom, S. J., and Wade, W. G. Design and Evaluation of useful Bacterium-specific PCR primers thatamplify genes coding for bacterial 16S rRNA. Applied Environmental Microbiology. 1998, 64, 795-799.

McCaig, A. E., Glover, L. A., and Professor, J. J. Numerical analysis of grassland bacterial community structure under different land management regimens by using $16 \mathrm{~S}$ rDNA sequence data and denaturing gradient gel electrophoresis banding patterns. Applied Environmental Microbiology. 2001, 67, 4554-59.

Murray, P.R., Baron, E. J., Pfaller, M.A., Tenover, F. C., and Yolke, R. H. (1995).Manual of Clinical Microbiology, $6^{\text {th }}$ Ed., ASM, Washington, DC.

Osborn, A. M., Moore, E. R. B., and Timmis, K. N. (2000). An evaluation of terminal restriction fragment length polymorphism (T-RFLP) analysis for the study of microbial community structure and dynamics. Environmental Microbiology. 200, 2, 39-50.

Parekh, J., and Chanda, S. In vitro antimicrobial activity of Trapanatans L. fruit rind extracted in different solvents. Af. J. Biotech. 2007, 6, 760- 770.

Prakash, P., Gupta, N. Therapeutic uses of Ocimum sanctum with a note on eugenol and its pharmacological uses. Indian journal of physiology and pharmacology. 2005,49(2),125-131.

Radfer, M. Sudarshana, M. Kavitha, H. Satish, H. Niranjan. M. Evaluation of antbacterial and antifungal activity of root and root callus extracts of Trianthema decandra L . Afr. J. Biotechnol, 2012, 11(2), 510-515.

Rahman, M. M. Sala Uddin, G.M. and Rahman, M.M. Efficacy of Various Organic Extracts of Piper Betle L. Leaves against Bacillus Spp. from Soil. Journal of Nature Science and Sustainable Technology, 2013, 7(2), 1-8.

Rahman, S, Parvez ,A.K, Islam, R, Khan, M.H: Antibacterial activity of natural spices on multiple drug resistant Escherichia coli isolated from drinking water, Bangladesh. Annal Clinical Microbiology and Antimicrobial. 2011, 10(1),10.

Shah, P. M. The need for new therpeutic agents: what is in the pipe line? Clinical Microbiology and Infection. 2005. 11, 36-42.

Sheikh, M. S., Islam, S., Rahman, A., Rahman, M., Rahman, M. M., Rahman, M. M., Rahim, A., and Alom, F. Control of some Pathogenic Bacteria by Seed Extracts of Cumin (Cuminum cyminum L.). Agricultural Conspectual Scientific. 2010, 75, 39-44

Sorokulova, I. B., Reva, O. N., Smirnov, V. V., Pinchuk, I. V., Lapa, S. V., and Urdaci, M. C. Genetic diversity and involvement in bread spoilage of Bacillus strains isolated from flour and ropy bread. Letting Applied Microbiology. 2003, 37, 169-73.

Tena, D., Mart'inez-Torres, J. A., P'erez-Pomata, M. T., S'aez-Nieto, J. A., Rubio, V., and Bisquert, J. Cutaneous infection due to Bacillus pumilus: report of 3 cases. Clinical Infectious Diseases. 2007, $44,40-42$.

Thompson, J. M., Waites, W. M., and Dodd, C. E. R. Detection of rope spoilage in bread caused by Bacillus species. Journal of Applied Microbiology. 1988, 85, 481-6.

Todar, K. Todar's online textbook of bacteriology: the genus Bacillus.University of WisconsinMadison, Department of bacteriology. 2005.

\section{Asian Business Consortium is an independent research house committed to publishing and delivering superior, Peer-reviewed standard research}




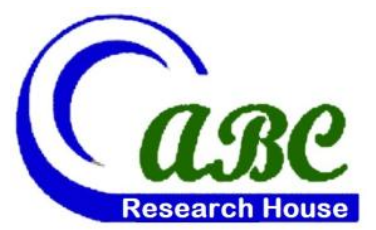

- Pantidalam, Kuala Lampur, Malaysia

- Rd 4, Shyamoli, Dhaka-1207, Bangladesh

- 3900 Woodhue Place, Alexandria, VA 22309, USA

www.abcreorg.weebly.com / www.abcjournals.net

Asian Business Consortium (ABC) is a multi-disciplinary research, training, publishing, digital library supporting and service house. Though founded in 2010 as the Business and Computing organization of Asia, it was reconstituted as the ABC in 2011. It has been working for creating and nurturing talents in USA, Malaysia and Bangladesh since its inception. As ABC is going global, it intends to open chapters in Australia, Germany, Japan, Pakistan, and other Asian countries in near future. The objectives of consortium are solely centered round the welfare and humane attitude of the founders who enthusiastically took up this noble cause and materialized it with a view to promote research and educational activities for the encouragement of scholars to develop their knowledge, to publish their analysis oriented scientific researches in international Journals, books, the task of organizing workshops, seminars, conferences, training, personality development programs and allied services.

In addition to research activities, ABC provides a good number of scholarships to the poor and meritorious students at various levels of education throughout the world. It plays an important role in the field of research by funding research projects and publishing the research papers. This consortium will unquestionably become the mouth-piece of the dark horses and unacknowledged scholar whose endowed and commendable contributions shall be provided an outlet keeping in mind the greater good of the larger society of the world.

$\mathrm{ABC}$ runs the following international referred journals for creating a platform to share the thoughts of professionals, scholars and academicians throughout the world.

\section{ABC Publications (ABC Journals)}

- Asian Accounting and Auditing Advancement (4A Journal)

- Asian Business Review (ABR)

- Asian Journal of Applied Sciences and Engineering (AJASE)

- Global Disclosure of Economics and Business (GDEB)

- $\quad$ ABC Journal of Advanced Research (ABC-JAR)

- International Journal of Reciprocal Symmetry and Theoretical Physics (IJRSTP)

- American Journal of Trade and Policy (AJTP)

- Asian Journal of Humanity, Art and Literature (AJHAL)

- Malaysian Journal of Medical and Biological Research (MJMBR)

- Asia Pacific Journal of Energy and Environment (APJEE)

- $\quad$ Engineering International (EI)

- $\quad$ ABC Research Alert (Online)

Each journal home page provides specific information for potential authors and subscribers. Open access policy, the quick review process, rich editorial boards and quality publications have already made $A B C$ Journals unique. ABC Journals are published under the direct supervisions of renowned academicians of the world.

Collaboration in Conference: ABC considers high-quality conference papers for publication. Please contact us for detailed information.

Collaboration in Publishing: If you like to start writing a book, propose a new journal or advertise in $\mathrm{ABC}$ journals, please feel free to contact us. 